\title{
Peran Dinas Tenaga Kerja dalam Proes Mediasi Penyelesaian Permasalahan Hubungan Industrial
}

\author{
Faizal Aditya Dermawan*, Bagus Sarnawa \\ Prodi Hukum, Fakultas Hukum, Universitas Muhammadiyah Yogyakarta, Indonesia \\ *Korespondensi : faizal.aditya.2016@law.umy.ac.id
}

\section{Info Artikel}

Diajukan: 20-06-2021

Direview: 24-06-2021

Direvisi: 26-06-2021

Diterima: 28-06-2021

DOI: $10.18196 / \mathrm{mls} . v 2 i 3.12076$

Abstrak

Penyelesaian Hubungan Industrial yang di selesaikan oleh Dinas Tenaga kerja dan Transmigrasi Kabupaten Bantul yang sudah di atur dengan dasar hukum Undang-Undang Nomor 2 Tahun 2004 tentang Penyelesaian Perselisihan Hubungan Industrial tersebut bertujuan untuk memperbaiki hubungan kerja sama antara buruh dan pengusaha, Penyelesaian ini diselesaiakan dengan proses arbitrase, konsiliasi, mediasi dan bipartite. Permasalahan yang akan di teliti: 1) Bagaimana peran Dinas Tenaga kerja di Kabupaten Bantul dalam menyelesaikan perselisihan hubungan indusrial melalui mediasi di Kabupaten bantul? 2) Apa saja faktor yang menghambat penyelesaian perselisihan hubungan industrial secara mediasi?Metode penelitian yang di gunakan dalam penelitian ini yaitu menggunakan yuridis empiris, dengan cara menggunakan pendekatan hukum dalam kenyataan atau berdasarkan fakta yang di dapat secara obyektif di lapangan baik berupa data, informasi dan paendapat yang di dasarkan pada identifikasi hokum. Dari hasil penelitian ini menunjukan : (1) Peran Dinas Tenaga Kerja dan Transmigrasi Kabupaten Bantul dapat menyelesaikan perselisihan hubungan industrial yang sudah di atur dalam Undang-Undang Nomor 2 Tahun 2004 yaitu dengan cara mufakat dan terdiri dari mediasi yang akan di pimpin oleh mediator, (2) Hambatan saat penyelesaian perselisihan hubungan industrial salah satunya adalah kurangnya pengetahuan kedua belah pihak dan tidak adanya kesepakatan atau berbeda pendapat sehingga menimbulkan perselisihan dan kurangnya pemahaman terhadap regulasi perundang-undangan ketenagakerjaan yang berbeda-beda, dan pihak ketiga pun akhirnya memberikan pendampingan kepada kedua belah pihak.

Kata Kunci : Hubungan Industrial, Penyelesaian, Perselisihan.

\section{Pendahuluan}

Pembukaan Undang Undang Dasar 1945 alinea ke empat, yang menyatakan bahwa negara Indonesia adalah negara yang bertujuan untuk mensejahterakan kehidupan rakyat Indonesia, maka pada saat ini negara Indonesia giat melakukan pembangunan pada semua aspek, tidak terkecuali aspek ekonomi. Pembangunan dibidang ekonomi ini kemudian memunculkan banyaknya dunia usaha. Dalam perkembangan selanjutnya timbulah hubungan antara pekerja dan pengusaha. 
Tenaga kerja adalah sebagai salah satu pihak yang dibutuhkan untuk terlibat dalam suatu proses pembanguna perekonomian. ${ }^{1}$ Secara normatif, hubungan antara pekerja dan pengusaha termasuk didalamnya pemerintah dikenal dengan istilah hubungan industrial. Hubungan Industrial merupakan hubungan yang terbentuk antara pelaku dalam proses produksi barang/jasa yang terdiri dari unsur pengusaha, pekerja dan pemerintah yang di dasari oleh Undang-Undang Dasar Negara Republik Indonesia Tahun1945.

Judul di atas menjelaskan tentang Peran yang di lakukan Dinas Tenaga Kerja di Kabupaten Bantul dalam melakukan mediasi atas perselisihan hubungan industrial di kabupaten bantul, Di kabupaten Bantul sendiri dua tahun belakangan ini mempunyai banyak kasus yang berkaitan dengan Hubungan industrial. Perselisihan hubungan industrial itu sendiri mempunyai permasalahan dengan internal perusahaan dan permasalahan hubungan industrial di Kabupaten Bantul ini kebanyakan permasalahannya itu seperti PHK sepihak dan pemotongan gaji, sedangkan permasalahan ini tersebut dapat di selesaikan dengan proses Mediasi,Bipartit,Konsiliasi, dan arbitrase. Faktor-faktor yang sangat berpengaruh besar yaitu internal perusahaan tersebut. Kondisi internal ini berperanpenting untuk menentukan hubungan antara pekerja/serikat kerja dengan pengusaha. Hubungan pekerja dan pengusaha yang serasi dan tanpa adanya konflik. Namun demikian ada kalanya timbul konflik atau perselisihan antara pekerja dan pengusaha sehingga akan merusak sistem hubungan industrial.

Perselisihan hubungan industrial itu sendiri merupakan suatu masalah yang tidak jauh dari proses industrialisasisuatu perbedaan pendapat atau kepentingan antara buruh dan pengusaha lainnya terjadi dalam suatu hubungan industrial.Permasalahan ketenaga kerjaan meurupakan hal yang sangat wajar karena sebagian besar penduduk Indonesia kini mulai beralih profesi dan lapangan kerja sangat banyak untuk di minati, dilain sisi penyelesaian masalah industrial tersebut menggunakan undang undang Nomor 22 Tahun 1957 Lembaran Negara Nomor 42 Tahun 1957 tentang Penyelesaian Perselisihan Perburuhan dan Undang-Undang Nomor 12 Tahun 1964 Lembaran Negara Nomor 93 Tahun 1964 tentang Pemutusan Hubungan Kerja di perusahaan swasta,Undang-Undang tersebut memberikan cara penyelesaian dengan mekanisme secara mufakat antara pihak satu dengan pihak lainnya melalui penyelesesaian mediasi atau arbitrase. Setelah beberapa saat Undang Undang tersebut sudah diganti yang lebih bisa memberikan jalan keluar yang bisa menyelesaikan masalah industrial tersebut Undang-Undang yang di yakini bisa memberikan jalan keluar permasalahan tersebut yaitu Undang-Undang Nomor 21 Tahun 2000 tentang Serikat pekerja dan Undang-Undang Nomor 2 Tahun 2004 tentang penyelesaian Perselisihan Hubungan Indrustrial adalah perbaikan peraturan bagi penyelesian berbagai perselisihan perburuhan atau lapangan kerja dan juga sebagai upaya untuk memberikan kepastian hukum dalam hubungan industrial di dunia pekerjaan.

\footnotetext{
${ }^{1}$ Sarnawa, B \&Isharyanto, J. E. (2010). Hukum Ketenagakerjaan. Yogyakarta: Laboratorium Ilmu Hukum, h.1.
} 
Penyelesaiaan hubungan industrial ini dapat di selesaikan dengan cara mediasi dan mediasi tersebut jika para pihak dalam waktu 30 hari perselisihan tersebut akan di selesaikan dengan cara Mediasi. Undang-Undang yang mengatur tentang penyelesaiaan Hubungan industrial ini mediasi tersebut dapat di lakukan apa bila penyelesaiaan tersebut tidak menemukan jalan keluar.mediasi sebagai salah satu cara penyelesaian yang dapat memberikan jalan keluar untuk menyelesaikan permasalahan hubungan industrial tersebut. Selain itu mediasi didukung berbagai faktor yaitu cara penyelesaian dikenal diberbagai budaya, bersifat non adversial, mengikutsertakan baik pihak yang langsung berkaitan maupun pihak yang tidak langsung berkaitan dengan sengketa dalam perundingan, dan bertujuan win-win solution. ${ }^{2}$

Mediasi adalah suatu cara untuk menyelesaikan perselisihan hubungan industrial yang meliputi perselisihan hak, perselisihan kepentingan pribadi, PHK, penyelesaian antar serikat pekerjaan. Dan penyelesaian dengan cara Mediasi itu di atur dalam Undang-Undang Nomor 2 Tahun 2004 tentang Penyelesaian Perselisihan Hubungan Indrustrial. Dan mediasi itu sudah di bantu dengan mediator yang mana memimpin proses mediasi tersebut di setiap kantor yang mengatasi atau bertanggung jawab berwenang menyelesikan suatu permasalahan di kota maupun kabupaten dan Dinas Tenaga Kerja dan Transmigrasi Kabupaten Bantul mempunyai kedudukan yang penting dalam menyelesaikan perselisihan hubungan industrial melalui proses mediasi sesuai dengan ketentuan 18 Undang-Undang Nomor 2 Tahun 2004 tentang Penyelesaian Perselisihan Hubungan Industrial. Di kurun waktu 2 Tahun belakangan ini Dinas Tenagakerja dan Tranmigrasi Kabupaten Bantul menyelesaikan 10 kasus yang di antaranya kasus tersebut rata-rata tidak hanya melibatkan satu orang karyawan melainkan beberapa karyawan dengan perusahaan pemberi kerja. Kasus ini juga penyebabnya perselisihan hubungan industrial itu ada empat yaitu karena hak, PHK, perelisihan antar serikat kerja dengan perusahaan dan kebanyakan kasus tersebut ratarata di perusahaan yang bergerak pada bidang garmen yang mempunyai banyak tenaga kerja dan mendominasi di Kabupaten Bantul, salah satu contohnya yaitu di PT kharisma export yang terletak di Kabupaten Bantul ini memiliki permasalahan hubungan industrial yaitu PHK secara sepihak tanpa memberikan pesangon. Masalah itu di selesaikan dengan proses mediasi. Proses Mediasi tersebut di lakukan karena untuk membantu pihak pihak yang mempunyai masalah hubungan industrial dan Mediator harus memberikan saran atau sesuatu yang bisa memberikan jalan keluar. Di dalam kerja Mediator tersebut tidak selalu berhasil dan tidak selalu mulus dalam menyelesaikan masalah industiral di karenakan, Mediator harus memberikan syarat syarat dan anjuran yang tertulis meminta agar pihak pihak tersebut harus bersepakat melalukan sesuatu. Dan apa bila suatu pihak yang tidak bisa menerima syarat-syarat dari mediator maka pihak tersebut harus menuangkan atau bersepakat ke dalam perjanjian bersama.

${ }^{2}$ Danang Sunyoto. (2013). Hak dan Kewajiban Bagi Pekerja dan Pengusaha. Yogyakarta: Pustaka Yustisia, h. 27. 


\section{MetodePenelitian}

Pendekatan yuridis empiris dengan menggunakan pendekatan hukum dalam kenyataan atau berdasarkan fakta yang didapat secara obyektif dilapangan baik berupa data, informasi, dan pendapat yang didasarkan pada identifikasi hukum efektifitas hukum merupakan pendekatan yang digunakan dalam penelitian ini. Sumber data penelitian yang digunakan dikelompokkan menjadi dua jenis, yaitu data primer dan sekunder. Dengan teknik pengumpulan data studi kepustakaan dan wawancara, dilanjutkan dengan analisa data. Analisis data dilakukan pada penelitian ini, dianalisis secara kualitatif dengan metode deskriptif, melalui pendekatan perundang-undangan dan pendekatan kualitatif, dianalisis secara kualitatif dan berpedoman Peraturan Menteri Ketenagakerjaan Republik Indonesia Nomor 2 Tahun 2004 Tentang Penyelesaian Perselisihan Hubungan Industrial.

\section{Hasil danPembahasan}

\subsection{Peran Dinas tenaga kerja dalam menyelesaikan perselisihan hubungan industrial melalui mediasi Kabupaten Bantul}

Pembukaan Undang-Undang 1945 pada dasarnya bertujuan untuk mewujudkan masyarakat adil, makmur dan sejahtera antara lain adanya pembangunan nasional di laksanakan antara lain pembangunan di bidang ekonomi. Pembangunan perekonomian akan melibatkan beberapa pihak, salah satunya adalah tenaga kerja. Pembangunan ketenagakerjaan di Negara Indonesia ini di dasarkan pada ketentuan Undang-undang Nomor 13 tahun 2003 tentang ketenagakerjaan. Undang-Undang Nomor 13 tahun 2003 ini dapat di katakana sebagai pengganti Undang-Undang Nomor 25 tahun 1997 tentang ketenagakerjaan dengan beberapa penyempurnannya. Seharusnya Undang-Undang Nomor 25 tahun 1997 dilaksanakan mulai tanggal 1 oktober 1988 namun urung dilaksanakan sebagai akibat adanya resistensi dari sekelompok pekerja. Akibatnya Undang-undang Nomor 11 tahun 1988 setelah dua tahun di tunda pekerja tetap melakukan resistensi terhadap keberlakuan Undang-Undang nomor 25 tahun 1997 untuuk melakukan pencabutan. Karena hal ini peraturan Pemerintah pengganti UndangUndang Nomor 3 tahun 2000 untuk mengakomodasikan keinginan para pekerja tersebut, sambil mempersiapkan rancangan Undang-Undang ketenagakerjaan sebagai pengganti Undang-Undang nomor 25 tahun 1977. Setelah pemerintah mengeluarkan Undang-Undang tentang ketenagakerjaan tersebut akhirnya perusahaan yang mempunyai pekerja atau buruh menggunakan Undang-Undang tersebut untuk memberikan pedoman kepada pekerja selain itu di suatu hubungan kerja yaitu adanya hubungan industrial. Ketentuan hubungan industrial yaitu Undang Nomor 2 Tahun 2004 Pasal 1 ayat (2) menyebutkan perselisihan hubungan industrial adalah perbedaan pendapat yang mengakibatkan pertentangan antara pengusaha atau gabungan pengusaha dengan pekerja/buruh atau serikat pekerja/serikat buruh karena adanya perselisihan 
antara hak, perselisihan kepentingan, perselisihan pemutus hubunngan kerja dan perselisihan antar serikat kerja. Penyelesaian hubungan industrial ada beberapa proses yaitu dengan cara mediasi, konsiliasi, arbitrase dan konsiliasi.

Salah satu proses tersebut meggunakan proses mediasi, yang di sebut mediasi merupakan suatu penyelesaian yang secara rinci dan hubungan industrial di atur dalam Permenaker Nomor 17 Tahun 2004 Tentang Pengangkatan dan pemberhentian mediator hubungan industrial serta tata kerja mediasi.Sebelum mediasi penyelesaian hubungan industrial dari pihak dinas tenaga kerjaan tersebut untuk menyelesaikan menawarkan pertama yaitu litigasi selanjutnya melalui rekonsiliasi dan aribatse setelah proses tersebut baru dinas tenaga kerja kabupaten bantul menawarkan penyelesaian hubungan industrial melalui mediasi. Hubungan antara pekerja dengan pengusaha tidak selamanya berjalan dengan baik-baik saja dan harmonis. ${ }^{3}$ Tidak terpenuhi hak dan tidak dilaksanakannya kewajiban masing-masing pihak mengakibatkan terjadinya perselisihan dalam hubungan tersebut. Diwilayah Kabupaten Bantul kerapkali terdapat perselisihan antara pekerja dengan pengusaha salah satunya yang permaslahanya yaitu pemutus hubungan kerja atau PHK. Selama waktu satu tahun terakhir ada 19 kasus pekerja yang hasilnya anjuran tertulis, di aajukan ke pengadilan hubungan industrial karena putusan anjuran tidak di sepakati oleh para pihak. Selamawaktu satu tahun tersebut di dalam sidang mediasi terdapat 198 kasus antara pekerja dengan pengusaha. Salah satu kasusnya yaitu PT Ameya di bulan februari yang akhirnya kasus tersebut di selesaikan dengan perjanjian bersama. Selanjutnya proses penyelesaian hubungan industrial melalui mediasi dan proses lainnya dari perselisihan hak, perselisihan kepentingan, perselisihan PHK dan perselisihan antara serikat pekerja melalui bipartit, dari bipartit sendiri yaitu menjadi tidak sepakat atau sepakat, tidak sepakat di selesaikan oleh disnaker setempat memalui mediator yang melalui proses mediasi, konsiliasi, arbitase dan putusan. Sedangkan dari sepakat melaui perjanjian dan didaftarkan ke disnaker dan selanjutnya ke eksekusi penyelesaian hubungan industrial tersebut. Perselisihan tersebut ditangani oleh Dinas Tenaga Kerja dan Transmigrasi Kabupaten Bantul khususnya mediator apabila ada laporan dari salah satu atau kedua belah pihak sudah terpenuhi makan proses penyelesian tersebut bisa di laksanakan. Proses penyelesaian perselisihan di luar pengadilan ini di selesaikan dengan cara bermusyawarah mufakat artinya mediator atau disnaker sebagai fasiliator dan pihak yang mendorong para pihak untuk menyelesaikan perselisihan hubungan industrial dengan cara melalui kesepakatan. ${ }^{4}$

Sesuai dengan ketentuan Undang-Undang Nomor 2 tahun 2004 tentang penyelesaian hubungan industrial maka dinas tenaga kerja dan transmigrasi Kabupaten Bantul memiliki peranan yang penting dalam menyelesaikan perselisihan hubungan

\footnotetext{
${ }^{3}$ Abd Latip, Lu'luiaily, Ainiyah, MEDIASI SEBAGAI PENYELESAIAN PERMASALAHAN TENAGA KERJA DI KABUPATEN BANGKALAN; Kompetensi vol 12 no 2, 2018

${ }^{4}$ Akbar, P. (2013). Alternative Penyelesaian Perselisihan Hubungan Industrial di Luar Pengadilan. Jurnal Ilmu Hukum, 9 (17)
} 
industrial melalui proses mediasi tidak hanya mediasi pemerintah juga harus mendukung proses penyelesaian arbitrase, konsiliasi dan bipartite. Proses tersebut juga berpengaruh besar terhadap penyelesaian suatu permasalahan hubungan industrial dan proses yang kerap di pakai untuk menyelesaiakan permasalahan tersebut yaitu mediasi. Kelancaran mediasi sangat berpengaruh besar terhadap peranan mediator. Pelaksanaan mediasi di Kantor Dinas Tenaga Kerja dan Transmigrasi Kabupaten bantul dapat di katakana baik atau tidak ada masaah sesuai dengan Undang-Undang Nomor 2 Tahun 2004 tentang Penyelesaian perselisihan hubungan industrial. Mediator Dinas Tenaga kerja dan Transmigrasi Kabupaten Bantul mempunyai peranan yang baik dalam menyelesakan perselisihan hubungan industrial antara pekerja dengan pengusaha.

Undang-Undang tersebut mengatur bahwa penyelesaian perselisihan hubungan industrial tersebut dapat di selesaikan dengan beberapa cara yaitu salah satunya mediasi dan di pimpin dengan mediator.

Di Dinas Tenaga Kerja dan Transmigrasi Kabupaten Bantul,terdapat lima mediator, yaitu:
a. An Nursina Karti, S.H.
b. Jumakir, S.Pd.
c. Bahari Toharuddin, S.E.
d. Sugeng Wahyudi, S.H.
e. Rini Widiastuti, S.H.

Mediator tersebut sudah memiliki persyaratan yang sesuai dengan di dalam Pasal 2 ayat (1) Permenaker Nomor 17 Tahun 2014 tentang pengangkatan dan pemberhentian Mediator Hubungan Indutrial serta tata kerja Mediasi, Syarat-syarat Mediator yaitu:

1. Beriman dan bertaqwa kepada Tuhan Yang Maha Esa

2. Warga Negara Indonesia

3. Pegawai Negeri Sipil pada instansi yang bertanggung jawab di bidang ketenagakerjaan

4. Berbadan sehat menurut surat keterangan dokter

5. Menguasai peraturan perundang-undangan di bidang ketenagakerjaan

6. Berwibawa, jujur, adil dan berkelakuan tidak tercela

7. Berpendidikan kurang-kurangnya Strata Satu (S1)

8. Memiliki sertifikat kompetensi

9. Memiliki surat keputusan pengangkatan dari Menteri 
Mediator tersebut sudah memenuhi syarat yang di tentukan dalam Peraturan Mentri Tenaga Kerja dan Transmigrasi Republik Indonesia Nomor 17 Tahun 2014. ${ }^{5}$ Peranan Mediator Dinas Tenaga Kerja dan Transmigrasi Kabupaten Bantul adalah:

1. Mediator meminta kepada para pihak untuk berunding sebelum di laksanakan proses mediasi. Para pihak harus mengadakan peundingan bipartite terlebih dahulu. Perundingan yang di lakukan para pihak yaitu pekerja dan pengusaha yng berselisih tanpa ada campur tangan pihak lain.

Instansi yang berwenang di bidang ketenagakerjaan harus menawarkan penyelesaian melalui konsisilasi atau arbitase seperti yang di sebutkan dalam Pasal 4 ayat (3) Undang-Undang Nomor 2 Tahun 2004 Tentang Penyelesaian Perselisihan Hubungan Industrial. Akan tetapi di Dinas Tenaga Kerja dan Transmigrasi Kabupaten Bantul tidak menggunakan metode penyeleseaian dengan cara seperti itu. Tetapi jika semua pihak sudah mencatatkan pada Dinas Tenaga kerja dan Transmigrasi Kabupaen Bantul dengan melampirkan bukti perundingan selanjutnya segera di selesaikan dengan metode proses mediasi.

2. Jika perundingan bipartit tidak berhasil salah satu pihak yang berselisih sudah mendaftarkan dan melampirkan bukti baha berundingan bipartite gagal di tempuh. Sebelum melakukan proses penyelesaian dengan cara mediasi, mediator membuat panggilan yang akan di sampaikan kepada para pihak yang berselisih untuk mengikuti proses sidang mediasi. Meditor hanya membuat panggilan selama tiga kali dan jika panggilan tiga kali pihak tersebut tidak bisa hadir maka akan di wakilkan dengan staf personalia perusahaan tersebut.

3. Di dalam sidang mediasi Mediator harus netral memimpin dan mengatur jalannya proses Mediasi. Sidang mediasi dapat di lakukan sekali hingga tiga kali pertemuan saja apabila sudah di temui kata sepakat dari para pihak. Akan tetapi dalam prakteknya selama kurun waktu setahun tersebut sebagian besar siding hanya berlangsung dua kali hingga tiga kali pertemuan sudah di temui kata sepakat para pihak. Apabila dalam proses Mediasi tersebut tidak menemukan titik terang atau adanya kesepakatan maka tugas mediator tersebut memberikan beberapa pilihan yang di ambil dari keterangan para pihak dan di serahkan kembali apakah akan menyetujui atau tidak pilihan yang di berikan mediator.

4. Di dalam sidang mediasi sudah ada kata sepakat maka di wajibkan dengan membuat Perjanjian Bersama (PB) yang di tanda tangani dan di setjui oleh pihak dan mediator dan setelah itu kemudia di daftarkan ke Pengadilan Hubungan Industrial (PHI) untuk mendapatkan akta bukti pendaftaran. Selama

\footnotetext{
${ }^{5}$ Hasil wawancara dengan ibu Rini widiastuti S.H. selaku Mediator di Dinas tenaga kerja dan Transmigrasi Kabupaten Bantul pada tanggal 15 Juni 2020 pukul 13.45 WIB
} 
kurun waktu satu tahun tersebut, tercatat ada 198 kasus pekerja yang hasilnya adalah Perjanjian Bersama, yaitu dalam sidang mediasi tersebut langsung ditemui kata sepakat dari para pihak sehingga mediator dan apabila tidak tercapai kata sepakat maka Mediator mengeluarkan anjuran tertulis. Anjuran tertulis dapat berubah se waktu waktu menjadi Perjanjian Bersama setelah semua di sepakati. Apabila para pihak tidak mensetujui maka salah satu pihak dan kedua belah pihak dapat mengajukan ke Pengadilan Hubungan industrial. Dari data yang bersumber dari Dinas Tenagakerja dan Transmigrasi Kabupaten Bantul bahwa kurun waktu satu tahun 2018 tercatat ada 19 kasus pekerja yang hasilnya Anjuran Tertulis dan tidak ada kesepakatan. Mediator sudah harus selesai membantu para pihak tersebut membuat Perjanjian Bersama sebagaimana tercantum dalam Pasal 13 ayat (2) huruf e Undang-Undang Nomor 2 Tahun 2004. Sedangkan pada Kantor Dinas tenaga kerja dan Transmigrasi Kabupaten Bantul setelah mengeluarkan anjuran tertulis di keluarkan oleh mediator dalam jangka waktu selambat-lambatnya 10 hari sejak Putusan Anjuran di terima, Para pihak memberian jawaban, dan itu lewat jangka waktu 3 hari kerja sejak anjuran tertulis tersebut disetujui.

Di selesaikan dengan proses mediasi harus melalui beberapa prosedur dan akhirnya bisa di selesaikan dengan cara mediasi atau dengan proses lainnya.

Bagan 1. Penyelesaian perselisihan hubungan industrial melalui proses mediasi dan lainnya

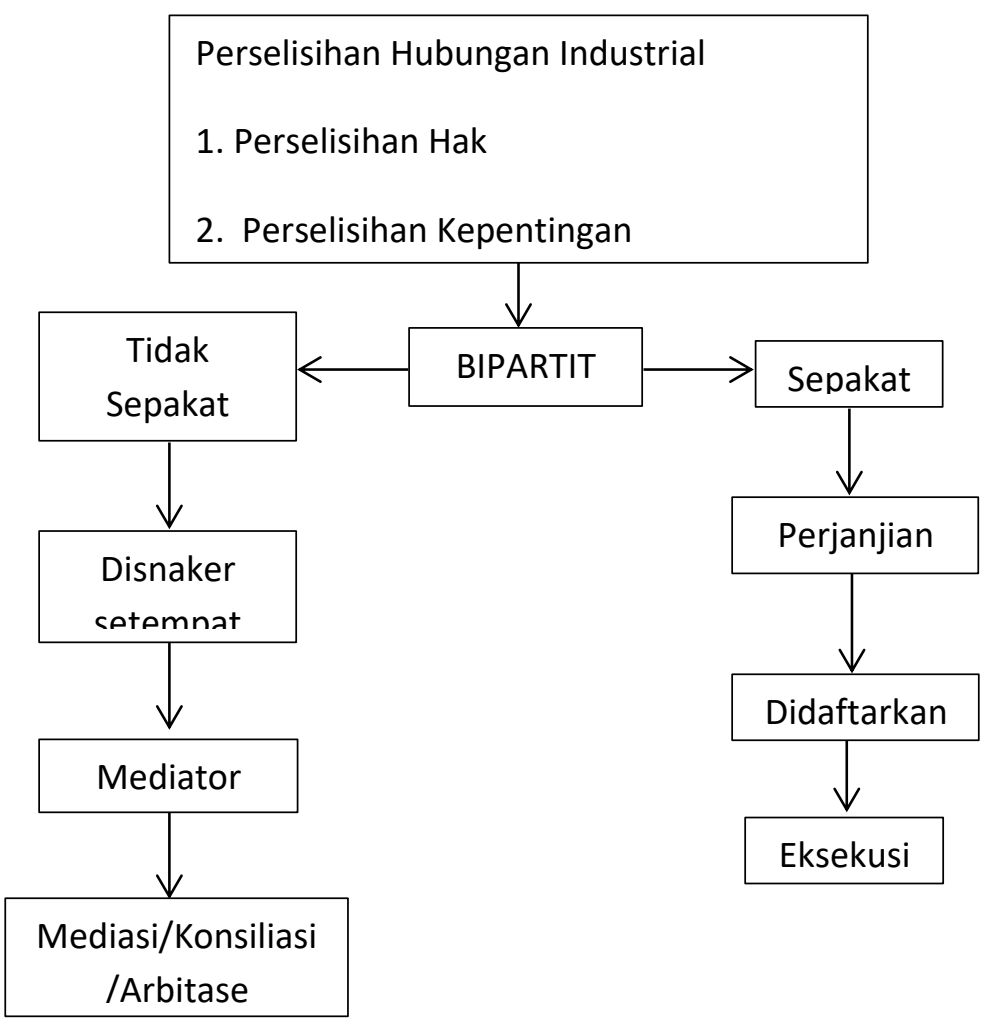


Bagan 1 menjelaskan bahwa perselisihan hubungan industrial yaitu perselisihan hak, perselisihan kepentingan, perselisihan PHK, perselisihan antara SP/SB tersebut di selesaikan dengan proses bipartite. Setelah bipartite yaitu memutuskan sepakat atau tidak sekapat, setelah sepakatmembuatsuatu perjanjian dan didaftarkan ke pengadilan hubungan industrial. Proses dari bipartityang tidak sepakat dalam perundingan antara pekerja/buruh dengan pengusaha untuk menyelesaikan permasalahan tersebut setelah itu jika tidak ada kesepakatan perundingan melalui bipartite maka disnaker setempat melakuikan penyelesaian dengan cara Mediasi, Konsiliasi, Arbitase. Dan menentukuan putusan.

Di sini kewenangan mediator hanya sampai di anjuran tertulis saja.Apabila para pihak sudah mensetjui kesepakatan tersebut dan di bawa ke Pengadilan Hubungan Industrial atau tidak, Sudah bukan lagi urusan mediator untuk menyelesaikan perselisihan Hubungan industrial tersebut. Tugas Mediator hanya 30 hari kerja terhitung dari menerima pelimpahan penyelesaian yang di sebut dalam Pasal 15 Undang-Undang Nomor 2 Tahun 2004 tentang penyelesaian perselisihan Hubungan Industrial. Dalam prakteknya mediator pada dinas tenaga kerja dan Transmigrasi Kabupaten Bantul menyelesaikan perselisihan sesuai ketentuan yang di tetapkan oleh Undang - Undang.

Peran Dinas Tenaga Kerja dan Transmigrasi dalam penyelesaian Perselisihan Hubungan Industrial sebgai mediator yang menyelesaikan perkara antara pekerja dengan pengusaha dapat di katakan membuahkan hasil karena dalam siding mediasi tersebut lebih banyak dihasilkan Perjanjian Bersama, yaitu sebanyak 198 Kasus Pekerja dari paa anjuran tertulis yang hanya terdapat 19kasus pekerja dalam kurun waktu satu tahun. Jadi, Penyelesaian perselisihan karena tidak perlu langkah selanjutnya setelah dalam siding mediasi di hasilkan perjanjian bersama.

\subsection{Hambatan - Hambatan Peran Dinas Tenaga kerja dan Transmigrasi dalam menyelesaikan Perselisihan Hubungan Industrial melalui Mediasi}

Peran Dinas Tenaga Kerja dan Transmigrasi Kabupaten Bantul sebagai Mediator dalam Penyelesaian Hubungan Industrial dan tentu saja mempunyai hambatan yang mempersulit untuk menyelesaikan perselisihan Hubungan Industrial Adapun hambatan yang terjadi saat proses penyelesaian hubungan industrial tersebut antara pekerja dan pengusaha salah satunya penyebabnya yaitu Risalah perundingan yang di lampirkan oleh pekerja pada saat mencatatkan perselisihan ke Dinas Tenaga kerja dan Transmigrasi Kabupaten Bantul hampir tidak terdeteksi karena kedua belah pihak tidak menuangkan secara formal dan tidak sampai di lakukan di Dinas tenaga kerja dan Transmigrasi kabupaten Bantul sebelumnya Mediator dalam memberikan perjanjian bersama kedua belah pihak memiliki hambatan tersendiri oleh mediator yaitu egosentris kedua belah pihak dalam proses sidang mediasi karena 2 kepentingan antara pekerja dan pengusaha berbeda beda. 
Selain menyelesaikan perselisihan Hubungan Industrial melalui Mediator Hambatan tersebut di temukan dalam pelaksanaan Penyelesaian Perselisihan Hubungan Industrial Melalui PHI sebagai berikut:

a. Dari aspek para pihak yang berselisih pekerja yang pendidikanya rata-rata masih rendah mengalami kesulitan dalam membuat surat gugatan apalagi beracara ke PHI, padahal pekerja/buruh tersebut ingin menyelesaikan perkara/perselisihannya ke PHI apabila pekerja ingin menggunakan kuasa hukum/advokat pekerja tidak meliki biaya. Demikian pula apabila ingin menggunakan kuasa hukum dari serikat pekerja/serikat buruh sebagaimana yang di maksud dalam Pasal 87 UU No.2 Tahun 2004, ternyata pekerja tidak tergabung dalam proses organisasi tersebut bekerja tidak memiliki organisasi serikat pekerja/buruh. Selain itu, apabila di dalam perusahaan dimana pekerja tersebut bekerja dalam organisasi serikat pekerja sehingga tidak menggunakan kuasa hukum dari serikat pekerja/serikat buruh ${ }^{6}$.

b. Dari aspek para pihak yang berselisih

Selama tahun 2006, belum ada pekerja/buruh yang beracra di PHI dengan di damping oleh kuasa hukum/advokat maupun yang menggunakan kuasa hukum dari serikat pekerja/buruh ketika beracara di PHI, ada bagian bekerja/buruh yang meminta bantuan kepada LBH Yogyakarta

c. Dari aspek pemanggilan para pihak

Dalam buku petunjuk yang di terbikan oleh MA menengani pelaksanaan UU NO.2 Tahun 2004, Menyatakan bahwa pemanggilan para pihak tersebutyang perkaranya bertempat tinggal di lar wilayah hukum PN setempat keududkan PHI dapat di didelegasikan kepala PN di tempat tinggal/tempat kedudukan pihak yang di panggil. Oleh karena itu pemanggilan terhadap para pihak yang berada di luar kota hukum PHI dapat melaksanakan pemanggilan pendelegasian.

Proses penyelesaian Hubungan Industrial yang memakan waktu lama yaitu di karenakan hambatan-hambatan yang ada di internal dan eksternal perusahaan. Proses penyelesaian tersebut sudah melalui banyak cara dengan proses mediasi dan arbitase. Hal ini memperlihatkan baha SP dan menejemen perusahaan itu sendiri berada di dalam presepsi yang tidak sepakat hingga menimbulkan perbedaan pendapat dan ketidakpuasan dari salah satu pihak. Hasil penelitian menemukan adanya sejumlah hambatan untuk menyelesaikan perselisihan Hubungan Industrial tersebut melalui aspek dari internal perusahaan. ${ }^{7}$ Hambatan yang berasal dari internal perusahaan yaitu:

a. Belum adanya Struktur karena serikat pekerja tersebut baru terbentuk dari beberapa tahun yang lalu, Seperti ini lah mengakibatkan belum adanya

\footnotetext{
${ }^{6}$ Misbahlul Munir. (2008). Hambatan-Hambatan dalam penyelesaian perselisihan hubungan industrial melalui pengadilan hubungan industrial. Jurnal ilmu hukum, 7(1), h. 140.

${ }^{7}$ Rakha Gusti Wardhana. (2019). Hambatan serikat pekerja dalam penyelesaian permasalahan hubungan industrial. Jurnal ilmu hukum, 20(3), h. 121.
} 
pembagian peran dan fungsi untuk membentuk tim yang terdiri dari kelompok yang melakukan pengkajian atau nalisis masalah yang terjadi coordinator lapangan setiap lini produksi yang bertugas untuk mencari fakta-fakta yang terjadi namun, jika hal ini terjadi proses perundingan dengan pihak manajemen maka seua tim akan hadir juga untuk berbicara permasalahan ini. Fossum (1982) menjelaskan bahwa atribut yang di miliki oleh serikat pekerja tersebut dapat menentukan senerapa lama proses perundingan permasalahan ini berlangsung. Terkait dengan kehadiran seluruh anggota juga membuat perundigan tidak berjalan dengan bauk. Rumondoang, Jaunaedah et.all (2014) dalam seri serikat pekerja menjelaskan bahwa jumlah anggota tim yang melakukan perundingan hanya terdiri dari 2-3 orang yang berperan sebagi pemimpin dan pengamat dalam jalannya perundingan atau mediasi. ${ }^{8}$

b. Kurangnya pengetahuan dan kemampuan pengurus SP untuk menentukan prioritas dalam permasalahan ini yang harusnya di selesaikan. Hal ini mengakibatkan semua persoalan di jadikan materi perundingan dan pengurus juga memiliki keterbatasan untuk mengkaitkan suatu masalah dengan pasalpasal yang di langgar dalam UU ketenagakerjaan. Kondisi ini terlihat ketika mempermasalahkan status pekerja borongan yang seharusnya berkaitan dengan pasal 65 dan 66 pada UU ketenagakerjaan namun yang di bicarakan ialah status pekerja PKWT yang terkait dengan pasal 9, sehingga mempersulit posisi mereka yang berhadapan dengan pihak manajemen perusahaan. Peserta perundingan harus memiliki pemahaman dan wawasam menengani permasalahan tersebut dan memiliki kepribadian yang tenang dalam menjalani situasi yang tekanan lebih lanjut di jelaskan bahwa SP harus menentukan priorotas dan keabsahan tuntutan dari segi hukum. Lemahnya kemampuan SP juga di jelaskan oleh silaban (2009) bahwa umumnya SP memliki kemampuan yang rendah untuk memahami masalah ekonomi, social dan politik serta memiliki keterbatasan tuntutan dari segi hukum.

c. Kurangnya motivasi beberapa anggota pengurus untuk bekerja sehingga yang terus bekerja hanya beberaapa orang saja. Hal ini terjadi karea beberapa anggota pengurus belum memahami dari SP. Kondis tersebut juga di jelaskan oleh Silaban (2009) bahwa kurangnya keseriusan anggota di sebabkan karena para pihak pengurs SP tidak memiliki waktu dan energy untuk terlibat secara aktif karena mereka juga harus bekerja lebih lama karena rendahnya pendapatan yang di peroleh sedangkan biaya hidup itu makin hari kain meingkat. Gerakan pekerja/buruh sehausnya tidak di kelola dengan suka rela dikarenakan solid dan efektif memiliki pengurus yang memiliki kemampuan analitik dan pengalaman yang mumpuni.

${ }^{8}$ Tanti Kirana Utami. (2013). Peran Serikat PekerjaDalam Penyelesaian Perselisihan Pemutus Hubungan Kerja. Jurnal Wawasan Hukum 28(1), h. 675. 
d. Selain itu juga adanya miss komunikasi antara anggota sehingga terjadi perbedaan terkait dengan materi perundingan. Miskomunikasi ini terjadi di karenakan adanya perbedaan penafsiran atau pengertian sehinga proses perselisihan Hubungan Industrial memakan waktu yang cukup lama. Di dalam serikat pekerja juga di sebutkan bahwa persiapan sebelum melakukan perundingan ini tim tersebut sebaiknya melakukan persiapan yang matang ehingga tida lagi adanya miss komunikasi anata para aggota sehingga perundingan akan berjalan dengan lancar.

e. Tidak adanya perjanjian kerja bersama yang mengatur penerapan pelaksanaan hubungan industrial sehinga keberadaan SP belum memiliki landasan yang kuat. Perjanjian kerja bersama berisi hak dan keajiban perusahaan serta hak dan kewajiban SP dan pekerja. Secara umum PKB memuat prjanjian tentang hubungan kerja, tata tertib kerja, pengupahan, keselamatan dan kesehatan kerja itu sangat penting. Dengan tidak adanya PKB berarti belum ada prosedur penyelesaian perselisihan secara harmonis sehingga kedua belah pihak terlibat dalam perseteruan yang berkepanjangan. Kemudan Fossum (1982) juga mengutarakan pemeliharaan hubungan industrial akan mempengaruhi kekuatan perundingan SP dan dengan tidak adanya PKB maka akan melemahkan kekuatan SP. Lebih lanjut di jelaskan oleh Silaban (2009) PKB merupakan suatu bentuk kemitraan antarapekerja dan pengusaha karena di dasarkan pada transparasi dan akuntabilitas dengan ini SP harus berupaya untuk melakukan negoisasi dengan perusahaan guna menghasilkan PKB yang lebih berkualitas.

Hambatan yang terjadi dari pihak eksternal perusahaan sebagai berikut:

1. Perusahaan menyangkal adanya pekerjaa borongan pada salah satu divisi pada lini produksi dan menanggap status kerja tersebut bukanlah suatu pelanggaran UU terkait dengan ketenagakerjaan khusunya yang berkaitan dengan Pasal 65 dan Pasal 66. Hal ini meruigkan pekerja borongan terutama dalam pemberian upah yang tidak di sesuaikan dengan perjanjian awal.

2. Menunda untuk mengabulkan tuntutan terkait dengan status kerja dari pekerja borongan dengan alasan kondisi keuangan perusahaan yang tidak memungkinkan walaupun sudah ada rekomendasi dari Dinas tenaga keja dan Transmigrasi setempat.

3. Melakukan pemutusan hubungan kerja terhada 3 orang pengurus SP dan 1 orang anggota SP tanpa ada alasan yang jelas sehingga perundingan kemudian lebih di arahkan pada penelesaian masalah tersebut dan akhirnya mendapatkan suatu keputusan untuk menyelesaikan masalah tersebut.

4. Pekerjaan borongan yang akan melakukan aksi mogok akan di ancam di PHK atau tidak akan di lakukan perubahan status kerjanya. 
Jika di lihat dari hambatan yang berasal dari perusahaan menujukan bahwa perusahaan masih melihat keberadaan SP bukan sebgai mitra untuk meciptakan kerja yang kondusif untuk meningkatkan produktivitas dan keberlangsungan perusahaan. Perusahaan melihat SP sebagai pihak yang bersebrangan karena memiliki kepentingan yang berbeda upaya untuk melemahan kedudukan SP dan anggotanya dengan ancaman pemecatan, tidak mengizinkan pekerja untuk membentuk SP dan lain-lain.Upaya yang di lakukan SP untuk mengatasi hambatan sebagai berikut:

1. Guna meningkatkan pengetahuan dan keterampilan negoisasi, pengurus khususnya tim perunding mengikuti pendidikan dasar dan lanjutan menegenai SP yang di selenggarakan oleh Federasi Serikat Kerja Metal Indonesia dengan materi antara lain keterampilan negoisasi an lain-lain dan di lanjutkan dengan konsultasi. Hal ini sebagaimana di jlaskan oleh Mills (1994), Silaban (2009) dan Rumondoang jaunedah et.all (2004) bahwa pengurus harus memiliki pengetahuan yang luas untuk melakukan negoisasi dengan baik. Di samping itu dengan adanya untuk menyelesaikan perselisihan hubungan industrial tersebut perlu mendapatkan dukungan dari piah luar yang dalam kasus ini adalah dukungan yang di peroleh dari Federasi Serikat Metal Indonesia.

2. Memaksimalkan peran tim yaitu dengan memanfaatkan sumberdaya yang tersedia. DI karenakan belum adanya struktur dalam kepengurusan, maka pengurus memanfaatkan tim yang telah di bentuk dengan selalu melakukan motivasi dan mengobarkan semangat untuk tiak putus asa dan trus berkonsiten memperjuangkan hak hak pekerja tersebut.

Guna mengatasi hal hambatan tersebut di perlukan upaya agar jangka waktu yang di butuhkan untuk menyelesaikan perselisihan Hubungan Industrial dapat lebih di persingkat yaitu dengan melakukan pemberdayaan kepada SP agar mampu untuk bernegoisasi, Merubah pandangan menjadi negative pekerja kepada SP dan perusahaan harus memiliki kesadaran yang sama untuk membangun hubungan industrial yang harminis demi tercapainya lingkungan kerja yang kondusif sehingga kebutuhan kedua belah pihak akhirnya terpenuhi dan mwncipatak kesejahteraan dalam lingkungan kerja.

Upaya yang di lakukan pihak mediator sebagai penengah penyelesaian perselisihan hubungan industrial sehingga tidak terjadi hambatan yaitu sebagai berikut:

1. Mediator memberikan kesadaran kepada pengusaha yang bermasalah tersebut dan meminta menaati peraturan perundang-undangan yang berlaku di ketenagakerjaan.

2. Meningkatkan kinerja dan pemerataan atas tugas mediator dengan jumlah yang banyak sehingga perselisihan Hubungan Industrial di berbagai daerah sehingga permasalahan tersebut bisa terselesaikan dengan baik dan menghasilkan lapangan kerja/serikat kerja yang baik di dalam masyarakat

3. Melakukan Konsolidasi penyelesaian Hubungan Industrial dengan 
menghadirkan pengusaha dan pekerja tersebut guna membahas mengenai peraturan perundang-undangan yang berlaku, serta mengupayakan dan berusaha menciptakan Hubunga Industrial yang harmonis, inamis, dan berkeadilan bagi masyarakat.

4. Secara khusus mediator juga melakukan sosialisasi pembinaan kepada perusahaan perusahan di kota khususnya di Kabupaten Bantul terutama di perusahan yang sering terjadi permasalahan Hubungan Industrial. Dari pembinaan tersebut yang di lakukan mediator dengan berkunjung ke perusahaan dan memberikan pemahaman mengenai peraturan ketenagakerjaan yang terkadang informasi tersebut di dapat pekerja hanya melalui media sosial saja. ${ }^{9}$

5. Mediator juga memberikan kesempatan kepada pengusaha maupun pekerja untuk berkonsultasi membicarakan tentang sutau Hubungan Industrial.

6. Melakukan pemberdayaan terhadap pekerja dan serikat buruh sehingga mereka memiliki bekal yang cukup dan wawasan yang luas mengenasi materu UndangUndang ketenagakerjan, teknik negoisasi, serta upaya menciptakan peran serikat pekerja dan serikat buruh dalam mewujudkan kerja yang harmonis di dalam suatu pekerjaan di perusahaan.

7. Melakukan pembinaan tentang perusahaan dan perjanjian kerja bersama. Pengusaha yang memiliki minimal 10 pekerja harus membuat peraturan perusahaan sebagai rujukan dalam melaksanakan suatu Hubungan Industrial di perusahaan maupun sebagai rjukan dalam menyelesaikan perselisihan Hubungan Industrial.

8. Melakukan penyelesaian mogok kerja dan unjuk rasa. JIka ada pekerja yang melaksanakan kegiatan mogok kerja maka mediator membantu melakukan pencegahan maupun pembinaan agar tidak terjadi hal yang tidak di inginkan, tetapi apabila akhirnya unjuk rasa tersebut di lakukan tetap harus ada mediasi antara perusahaan dan pekerja tersebut.

\section{Simpulan}

Dinas tenaga kerja dan transmigrasi Kabupaten Bantul berperan penting untuk menyelesaikan melalui mediasi dan di bantu oleh Mediator. Dan mediasi itu sendiri yaitu proses penyelesaian perselisihan hubungan industrial melalui kesepakatan bersama atau mufakat. Di alam mediasi tersebut di bantu oleh mediator, mediator untuk menyelesaikan perselisihan hubungan industrial ini yaitu guna untuk menyelesaikan perselisihan secara musyawarah dan mufakat. Proses Penyelesaian melalui mediasi tersebut pun banyak peselisihan Hubungan Industrial yang terselesaikan dan dari tahun 2018 di Kabupaten Bantul beberapa kasus sudah selesai dan dengan kesepakatan

\footnotetext{
9 Hasil wawancara dengan Bapak Bahari toharudin selaku bidang mediasi DInas Tenagakerja dan Transmigrasi Kabupaten Bantul pada tanggal 15 Juni 2020 Pukul 14.00 WIB
} 
perjanjian bersama. dan sesuai dengan prosedur penyelesaian Hubungan Industrial yang di sebutkan dalam Undang-Undang Nomor Tahun 2004 tentang Penyelesaian Peselisihan Hubungan industrial.

Adanya salah paham komunikasi antara perusahaan dan pekerja dan kurangnya sebuah wawasan tentang Undang-Undang Ketenagakerjaan tentang peraturan peraturan tersebut. Dan untuk mencegah adanya hambatan proses perselisihan Hubungan Industrial tersebut mediator mempunyai cara tersendiri yaitu salah satunya mengadakan pembinaan kepada perusahaan dan pekerja yang sering terjadi perselisihan dan tugas mediator harus bisa membeikan suatu masukan sehingga kedua belah pihak yang bermasalah dapat mengerti dan maslah perselisihan Hubungan Industrial tersebut terselesaikan dan menciptakan Hubungan kerja atau Industrial yang harmonis dan berkeadilan.

\section{Daftar Pustaka}

\section{Buku}

Danang Sunyoto. (2013).Hak dan Kewajiban Bagi Pekerja dan Pengusaha.Yogyakarta: Pustaka Yustisia.

Fajar, M \& Achmad, Y. (2010). Dualisme Penelitian Hukum Normatif \& Empiris. Yogyakarta: Pustaka Pelajar.

Sarnawa, B \& Isharyanto, J. E. (2010).Hukum Ketenagakerjaan, Yogyakarta: Laboratorium Ilmu Hukum.

\section{Regulasi}

Undang-Undang Nomor 2 Tahun 2004 tentang Penyelesaian Perselisihan Hubungan Industrial.

\section{Jurnal}

Akbar, P. (2013). Alternative Penyelesaian Perselisihan Hubungan Industrial di Luar Pengadilan. Jurnal Ilmu Hukum, 9 (17).

Rakha Gusti Wardhana. (2019). Hambatan serikat pekerja dalam penyelesaian permasalahan hubungan industrial. Jurnal ilmu hukum, 20(3).

Tanti Kirana Utami. (2013). Peran Serikat PekerjaDalam Penyelesaian Perselisihan Pemutus Hubungan Kerja. Jurnal Wawasan Hukum 28(1).

Abd Latip, Lu'luiaily, Ainiyah, Mediasi Sebagai Penyelesaian Permasalahan Tenaga Kerja di Kabupaten Bangkalan; Kompetensi vol 12 no 2, 2018 


\section{Wawancara}

Ibu Rini widiastuti S.H. Mediator Dinas tenaga kerja dan Transmigrasi Kabupaten Bantul.Wawancara.Bantul. 15 Juni 2020. Pukul 13.45 WIB. 